\title{
Caries prevalence and risk factors among children aged 0 to 36 months
}

\section{Prevalência de cárie e fatores de risco em crianças de 0 a 36 meses}

\author{
Ana Paula Pires dos Santos* \\ Vera Mendes Soviero**
}

\begin{abstract}
The aim of this study was to assess the prevalence of caries and risk factors in outpatients of the Pediatric Ambulatory of the Pedro Ernesto University Hospital aging up to 36 months. After signing informed consent forms, the parents answered a structured questionnaire in order to evaluate risk factors for dental caries, including socioeconomic status, oral hygiene and dietary habits. A single investigator carried out the dental examination which assessed the presence of caries, biofilm and gingival bleeding. The data were analyzed by means of the Epi Info program, utilizing the chi-squared test. The children's mean age was 22.9 months. The prevalence of caries, including white spot lesions, was $41.6 \%$, and the mean def-s was $1.7( \pm 2.5)$. The most affected teeth were the maxillary incisors, and the most common lesion was the white spot. No significant associations were found between the prevalence of caries and socioeconomic status, frequency of oral hygiene, nocturnal bottle- and breast-feeding or cariogenic food and beverage intake during the day. However, the association between caries and oral hygiene quality (dental biofilm) was statistically significant $(\mathrm{p}<0.001)$. The results suggest that the presence of a thick biofilm was the most important factor for the occurrence of early childhood caries in the evaluated sample.
\end{abstract}

UNITERMS: Dental caries; Primary prevention; Infant; Child, preschool.

\begin{abstract}
RESUMO: O objetivo deste trabalho foi avaliar a prevalência de cárie e de fatores de risco em crianças com idade até 36 meses cadastradas no Ambulatório de Pediatria do Hospital Universitário Pedro Ernesto (HUPE-UERJ). Após a obtenção de consentimento livre e informado, foi realizada uma entrevista com os responsáveis por meio da qual foram avaliados os fatores de risco à cárie, incluindo condições sócio-econômico-culturais, hábitos de higiene oral e de dieta. Um único examinador realizou o exame bucal das crianças para a avaliação de cárie, de biofilme dental e de sangramento gengival. Os dados obtidos foram analisados através do programa Epi Info, utilizando-se o teste qui-quadrado. As crianças tinham em média 22,9 meses de idade. A prevalência de cárie encontrada, incluindo lesões não cavitadas, foi de $41,6 \%$ e o índice ceo-s foi de $1,7( \pm 2,5)$. Os dentes mais afetados foram os anteriores superiores e o tipo de lesão mais comum foi a mancha branca ativa. Não houve associação significativa estatisticamente entre a prevalência de cárie e os fatores sócio-econômico-culturais, freqüência de higiene, hábito de amamentação noturna e dieta cariogênica durante o dia. Entretanto, a associação entre cárie e presença de biofilme dental foi considerada altamente significativa $(\mathrm{p}<0,001)$. Os resultados sugerem que o acúmulo de biofilme dental espesso foi o fator preponderante para a ocorrência da cárie de estabelecimento precoce na amostra avaliada.
\end{abstract}

UNITERMOS: Cárie dentária; Prevenção primária; Lactente; Pré-escolar.

\section{INTRODUCTION}

Nursing caries was first described by Dr. Fass ${ }^{9}$ in 1962. Since then, many terms have been used to define it: rampant caries, nursing bottle mouth, baby bottle tooth decay, among others. However, in 1994, the Centers for Disease Control and Prevention in the United States proposed the utilization of a less specific term, childhood caries, since the etiology of this pattern of caries could not be attributed only to the utilization of a baby bottle.
Early childhood caries lesions affect initially the primary upper incisors and they clinically appear as white spots along the gingival margin. In advanced cases, the crowns can be completely destroyed. Since the first caries lesions can develop as soon as the primary upper incisors erupt, it is very important that parents and caretakers are able to recognize the first clinical signs of the disease ${ }^{7}$.

Studies about the prevalence of caries in children between the ages of 0 and 36 months reveal

\footnotetext{
* Specialist in Pediatric Dentistry, School of Dentistry, University of the State of Rio de Janeiro.

**Assistant Professor, Department of Pediatric Dentistry, School of Dentistry, University of the State of Rio de Janeiro and Estácio de Sá University.
} 
Santos APP dos, Soviero VM. Caries prevalence and risk factors among children aged 0 to 36 months. Pesqui Odontol Bras 2002;16(3):203-208.

TABLE 1 - Criteria utilized in the assessment of dental biofilm (Ribeiro et al.22, 1999)

\begin{tabular}{c|l}
\hline \hline 0 & No visible biofilm \\
\hline 1 & Thin biofilm only on anterior teeth \\
\hline 2 & $\begin{array}{l}\text { Easily removed thin biofilm, distributed on anterior and } \\
\text { posterior teeth }\end{array}$ \\
\hline 3 & $\begin{array}{l}\text { Firmly adhered thick biofilm, only on anterior or poste- } \\
\text { rior teeth }\end{array}$ \\
\hline 4 & $\begin{array}{l}\text { Firmly adhered thick biofilm on anterior teeth and thin } \\
\text { biofilm on posterior teeth, or firmly adhered thick bio- } \\
\text { film on posterior teeth and thin biofilm on anterior } \\
\text { teeth }\end{array}$ \\
\hline 5 & $\begin{array}{l}\text { Firmly adhered thick biofilm on anterior and posterior } \\
\text { teeth }\end{array}$ \\
\hline \hline
\end{tabular}

various indexes, probably due to the existence of socioeconomic and cultural differences ${ }^{2,4,6,10,11,12,15}$.

Epidemiological data show that the most effective approach for the control of early childhood caries is based on the prevention and not on the restorative treatment. The ideal conduct would be to provide expectant mothers with counseling and guidance, since one of the greatest difficulties related to the control of early childhood caries is the fact that few parents take their children to the dentist before the age of three years ${ }^{13}$. Despite this, medical appointments are very frequent at this age, which makes interesting the presence of a dental professional in the medical office, so that children can also have a dental follow-up since their birth.

The aim of this study was to evaluate the prevalence of caries in outpatients of the Pediatric Ambulatory of the Pedro Ernesto University Hospital aged 0 to 36 months, and also to evaluate the presence of risk factors for dental caries, such as socioeconomic status, parents' knowledge concerning dental care, oral hygiene and dietary habits.

\section{MATERIAL AND METHODS}

Eighty children of both genders were selected. To be included in the sample, the child should be an outpatient of the Pediatric Ambulatory of the Pedro Ernesto University Hospital, aging from 0 to 36 months. All parents signed an informed consent form and answered a structured questionnaire in order to evaluate the risk factors for dental caries, including socioeconomic status, parents' knowledge concerning dental care, oral hygiene and dietary habits.
TABLE 2 - Criteria utilized in the assessment of gingival bleeding (Ribeiro $\left.{ }^{21}, 2000\right)$

\begin{tabular}{l|l}
\hline \hline 0 & No bleeding \\
\hline 1 & Bleeding after probing \\
\hline 2 & Spontaneous bleeding \\
\hline \hline
\end{tabular}

TABLE 3 - Criteria utilized in the diagnosis of caries (Carvalho et al. ${ }^{5}$, 1992; Bjørndal et al. ${ }^{3}$, 1997)

\begin{tabular}{c|l}
\hline \hline 0 & Sound \\
\hline 1 & $\begin{array}{l}\text { Active lesion in enamel, without cavity (opaque enamel } \\
\text { with a white spot on the surface) }\end{array}$ \\
\hline 2 & $\begin{array}{l}\text { Inactive lesion in enamel, without cavity (bright surfa- } \\
\text { ce with brown discoloration) }\end{array}$ \\
\hline 3 & $\begin{array}{l}\text { Active cavity in enamel (opaque enamel surface and } \\
\text { loss of substance) }\end{array}$ \\
\hline 4 & $\begin{array}{l}\text { Inactive cavity in enamel (bright surface, brown disco- } \\
\text { loration and loss of substance) }\end{array}$ \\
\hline 5 & $\begin{array}{l}\text { Active cavity in enamel/dentin (yellow or light brown } \\
\text { discoloration, wet dentin) }\end{array}$ \\
\hline 6 & $\begin{array}{l}\text { Inactive cavity in enamel/dentin (dark brown discolora- } \\
\text { tion, hard and dry dentin) }\end{array}$ \\
\hline 7 & Pulpal involvement or root stumps \\
\hline 8 & Filled tooth \\
\hline 9 & Missing tooth \\
\hline \hline
\end{tabular}

A single investigator carried out the children's dental examination in a dental office. The child remained laid in a specific stretcher (MACRI ${ }^{\circledR}$ ). The examination was carried out under dental light, and mouth mirrors were utilized. Caries, dental biofilm and gingival bleeding were assessed in this examination.

The biofilm was visually inspected, without disclosing solutions, and it was classified according to the index proposed by Ribeiro et al. ${ }^{22}$ (1999) (Table 1).

Gingival bleeding was assessed by means of periodontal probing in each of the erupted dental surfaces (Ribeiro $\left.{ }^{21}, 2000\right)$ (Table 2).

Dental examination was carried out after the biofilm was removed with a toothbrush or a gauze pad. Each of the dental surfaces was classified according to the criteria of Carvalho et al. ${ }^{5}$ (1992) and BjØrndal et al. ${ }^{3}$ (1997) (Table 3).

The intra-examiner confidence interval for dental caries was evaluated by means of the reexamination of a group of children equivalent to $10 \%$ of 
Santos APP dos, Soviero VM. Caries prevalence and risk factors among children aged 0 to 36 months. Pesqui Odontol Bras 2002;16(3):203-208.

the sample. The Kappa test was used and its value was inferior to 0.90 .

This study was validated by the Ethical Committee of the Rio de Janeiro Sate University, and the data were analyzed by means of the Epilnfo software, utilizing the Chi-square test. P-values equal or inferior to 0.05 were considered statistically significant.

All parents and caretakers received information on caries control and prevention during the appointments and by means of explicative leaflets.

\section{RESULTS}

The sample consisted of 80 children aged 0 to 36 months (mean $=22.9 \pm 8.9$ ), divided in three age groups: 0 to $12(13.8 \%-11$ subjects), 13 to 24 $(32.5 \%-26$ subjects) and 25 to 36 months (53.8\% - 43 subjects). There were 35 girls (43.8\%) and $45(56.3 \%)$ boys. Regarding the economic status, $50 \%$ of the parents reported incomes of up to 3 minimum salaries, $48.6 \%$, between 4 and 7 , and only one family (1.4\%) had an income superior to 8 minimum salaries. The mean period of school attendance was $7.4( \pm 3.4)$ years for mothers and 6.9 $( \pm 3.0)$ years for fathers, which characterizes low schooling level. The majority of the children $(92.5 \%)$ had never been examined by a dentist before.
From all evaluated children, 21.3\% (17) were still being breast-fed and $71.3 \%$ (57), bottle-fed. Among these, 80\% (59) were being breast-/bottle-

TABLE 4 - Data on caries risk factors obtained in the interview (80 children).

\begin{tabular}{l|c|c}
\hline \hline \multirow{2}{*}{ Risk factors } & \multicolumn{2}{|c}{ Answer } \\
\hline \multirow{2}{*}{ Hygiene } & Yes & No \\
\cline { 2 - 3 } & $76.3 \%(61)$ & $24.7 \%(19)$ \\
\hline \multirow{2}{*}{ Hygiene frequency* } & $1-2$ times & 3 or more \\
\cline { 2 - 3 } & $72.9 \%(43)$ & $27.1 \%(16)$ \\
\hline \multirow{2}{*}{ Breast-/bottle-feeding at night } & Yes & No \\
\cline { 2 - 3 } & $73.7 \%(59)$ & $26.3 \%(21)$ \\
\hline \multirow{2}{*}{$\begin{array}{l}\text { Hygiene after nocturnal } \\
\text { breast-/bottle-feeding }\end{array}$} & Yes & No \\
\hline \multirow{2}{*}{\begin{tabular}{l} 
Cariogenic diet \\
\cline { 2 - 3 }
\end{tabular}} & $3.4 \%(2)$ & $96.6 \%(57)$ \\
\hline \multirow{2}{*}{$\begin{array}{l}\text { Frequency of sacarose con- } \\
\text { sumption }\end{array}$} & $75 \%(60)$ & $25 \%(20)$ \\
\hline \multirow{2}{*}{\begin{tabular}{l} 
Fluoride utilization \\
\cline { 2 - 3 }
\end{tabular}} & $69 \%(52)$ & $31 \%(28)$ \\
\cline { 2 - 3 } & $67.4 \%(54)$ & $32.6 \%(26)$ \\
\hline \hline
\end{tabular}

*Two mothers did not answer this question.

TABLE 5 - Association between caries and the studied variables (77 children).

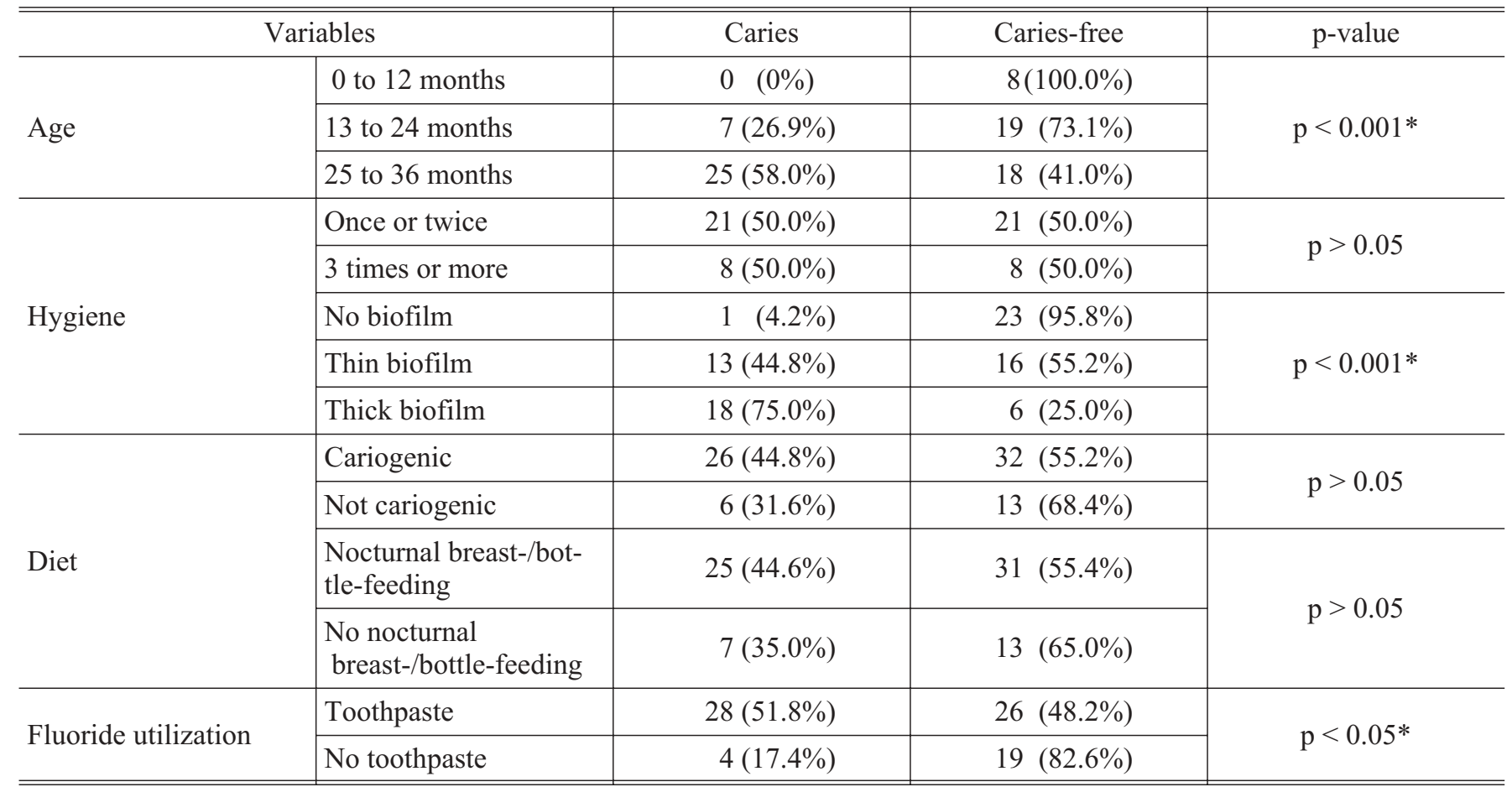

* Statistically significant. 
Santos APP dos, Soviero VM. Caries prevalence and risk factors among children aged 0 to 36 months. Pesqui Odontol Bras 2002;16(3):203-208.

fed to fall asleep. Moreover, 75\% (60) of the children had a cariogenic diet during daytime, and $69 \%$ (52) presented frequent consumption of sugar-containing beverages. Regarding oral hygiene, $47.5 \%$ (38) of the parents reported to be aware of its importance and able to carry it out. This kind of information had been given by dentists $(26.3 \%-10$ cases $)$, pediatricians $(26.3 \%-10$ cases) or others $(47.4 \%-18$ cases $)$. Among the parents, $76.3 \%$ (61) assured that they cleaned their children's teeth but only $3.3 \%$ (2) cleaned them even after nocturnal breast-/bottle-feeding at night. In $70.5 \%$ (43) of the cases, hygiene was carried out once or twice a day and in $26.2 \%(16)$, three or more times a day. The toothbrush was used in $88.5 \%$ (54) of the cases and the dental floss in $8.2 \%(5)$. Other methods adopted were the finger toothbrush (1.6\% - 1 case) and gauze pad or nappy $(23 \%-14$ cases). Concerning the utilization of fluoride, $67.5 \%$ (54) of the children utilized fluoridated toothpastes. Among these, 83.3\% (45) had used it for the first time between 1 and 2 years old. The majority of parents (95\% - 76 subjects) believed that dental caries could be prevented. The most frequently mentioned preventive measures were the cleaning of teeth (65.8\% - 50 subjects), sugar restriction $(33 \%-25$ subjects) and dental treatment (15.8\% - 12 subjects). Despite believing in prevention, $11.8 \%$ (9) of the parents did not know how to promote it. Table 4 summarizes the data on dental caries risk factors obtained in the interview.

As to the assessment of biofilm, which was carried out in the 77 children who presented with erupted teeth, $37.7 \%$ (29) had thin biofilm and $31.2 \%$ (24), thick biofilm. Only one child (1.3\%) presented with spontaneous bleeding. The prevalence of caries was $41.6 \%$ (32), and the mean def-s was $1.7( \pm 2.5)$. From all the children who had caries, $87.5 \%$ (28) presented lesions in upper incisors/canines, $9.4 \%$ (3) in lower incisors/canines, $34.4 \%$ (11) in first molars and $12.5 \%$ (4) in second molars. There were 135 dental surfaces affected by caries. Among these, 57 (42.2\%) were active white spots, $2(1.5 \%)$ inactive white spots, $18(13.3 \%)$ enamel cavities, $52(38.5 \%)$ dentinal cavities and 6 $(4.4 \%)$ restored surfaces.

The association between caries and sex, number of brothers and sisters or socioeconomic and cultural status, was not statistically significant. $(p>0.05)$. However, the association between the age group and the presence of caries was statistically significant $(\mathrm{p}<0.001)$. All of the 8 children who belonged to the age group of 0 to 12 months were caries-free, but, among the 43 children aged 25 to 36 months, 18 (41.8\%) had caries (Table 5).

No influence of hygiene frequency, nocturnal breast-/bottle-feeding or cariogenic diet intake during daytime was observed on the prevalence of caries ( $p>0.05)$. However, the association between the prevalence of caries and the presence of biofilm was highly significant $(\mathrm{p}<0.001)$. Only one child $(4.2 \%)$, among the 24 who had no visible biofilm, had caries. Among the subjects with thin biofilm (29), 13 (44.8\%) had caries, and, among the 24 children with thick biofilm, $18(75 \%)$ had caries. Since only one child presented with gingival bleeding, this item was not associated to the other studied aspects.

\section{DISCUSSION}

Several studies on the prevalence of caries in children aging up to 36 months have been carried out in many countries. The prevalence of early childhood caries varies: $11.7 \%$ in Sweden ${ }^{11}, 62.6 \%$ in Puerto Rico ${ }^{14}$ and $16.7 \%$ in Brazil $^{15}$. In this study, the prevalence of caries and the mean def-s found were, respectively, $46.1 \%$, and 1.7 . Confirming the findings of other reports ${ }^{2,4,6,10,11,12,14,20}$, the most affected teeth, in this study, were the upper incisors, and the prevalence of caries and the severity of the disease increased according to the increase of age. This fact suggests that teeth are affected by caries in the sequence of eruption if no measure is adopted in order to control the risk factors as soon as the first sign of caries is detected. Thus, the need for dental assistance during the first year of life must be pointed out, since at that time it is still possible to prevent the development of initial lesions or to control the disease in case it is already established.

Epidemiological data obtained from samples composed of subjects of different socioeconomic status revealed that the prevalence of early childhood caries was strongly related to the families' socioeconomic level. The lower the social level, the higher the prevalence of early childhood caries ${ }^{11,19}$. That result differs from the findings of this study because the evaluated sample was very homogeneous as to socioeconomic and cultural status.

As in this study, other surveys have not found statistically significant associations between hygiene frequency and caries ${ }^{18,19}$. However, hygiene quality, evaluated through the presence of biofilm, was the risk factor most strongly associated with the prevalence of caries. From the children who had thick biofilm, $75 \%$ presented with caries, 
Santos APP dos, Soviero VM. Caries prevalence and risk factors among children aged 0 to 36 months. Pesqui Odontol Bras 2002;16(3):203-208.

against $44.8 \%$ of those who had thin biofilm and $4.2 \%$ of those who presented with no visible biofilm. Other studies have also concluded that the accumulation of biofilm was the main risk factor for dental caries in children under 3 years old $^{1,18}$. These results reveal the need for a better guidance of parents and caretakers on how to carry out effective oral hygiene in children. More important than the habit of tooth brushing many times a day is the ability to disorganize the biofilm, at least once a day.

Although many authors $\mathrm{s}^{6,8,23,24}$ report an association between nocturnal bottle-/breast-feeding and early childhood caries, it was not possible, in this study, to assure this association. More than 55\% of the children who were bottle-/breast-fed at night did not develop caries. That suggests that other factors also contributed to the establishment or prevention of the disease. That supports the replacement of the term nursing caries by the term early childhood caries, since the etiology of caries in young children can not be focused only in the utilization of a baby bottle.

The association between cariogenic food intake during the day and the prevalence of caries was not statistically significant. Many authors have reported how complex it is to analyze a diet. Even if it is a very good analysis, it will always be only an estimation $^{8,10}$. In this study, the diet was classified in cariogenic or not cariogenic, according to the information obtained from the parents during the interview, which might have underestimated the analysis of this risk factor.

The most common lesion found in this study was the white spot (24.7\% of the children). That has also been reported in many other studies ${ }^{2,4,11,14,23}$. This type of lesion can develop in children under 12 months. That is why the first dental appointment should take place before this age, so that the professional can evaluate the risk factors and prevent or control the disease. Parents should be provided

\section{REFERENCES}

1. Alaluusua S, Malmivirta R. Early plaque accumulation - a sign for caries risk in young children. Community Dent Oral Epidemiol 1994;22(5 pt1):273-6.

2. Arias SMB, Brandão AMM, Nogueira AJS. Prevalência de cárie em bebês de 0-3 anos. RGO 1997;45(3):163-9.

3. BjØrndal L, Larsen T, Thylstrup A. A clinical and microbiological study of deep carious lesions during stepwise excavation using long treatment intervals. Caries Res 1997;31(6):411-7. with information on dental care during pregnancy, which favors the scheduling of an early dental appointment for the baby. Furthermore, it is easier to prevent inappropriate habits than to try to eliminate them after they are inserted in the daily routine. Another proposal is to train parents and caretakers to detect the first clinical signs of the disease. Information on the diagnosis of caries enable parents not only to detect caries but also to consider the white spot as a real caries lesion ${ }^{16}$.

The prevention of early childhood caries depends on multidisciplinary efforts, involving different health professionals and government sectors responsible for investments in health. Strategies providing the population with information and encouraging families to change their attitudes towards oral health should be implemented. The information should be practical and objective so that families feel capable of inserting preventive attitudes in their lives. A longitudinal study involving the evaluated sample would be extremely relevant in order to observe the assimilation of information and motivation related to preventive methods.

\section{CONCLUSIONS}

The prevalence of caries in this study was $41.6 \%$ and the mean def-s was $1.7( \pm 2.5)$. The most affected teeth were the upper incisors and the white spot was the most frequently diagnosed type of lesion.

The association between caries and socioeconomic and cultural status, hygiene frequency, cariogenic diet and nocturnal breast-/bottle-feeding was not statistically significant $(p>0.05)$. However, the association between caries and hygiene quality was highly significant ( $<<0.001)$.

Encouraging parents to take their children to the dentist before the age of 1 year, so that they can be provided with guidelines for caries prevention, seems to be the most effective way to prevent and control early childhood caries.

4. Bönecker MJS, Guedes-Pinto AC, Walter LRF. Prevalência, distribuição e grau de afecção de cárie dentária em crianças de 0 a 36 meses de idade. Rev Assoc Paul Cir Dent 1997;51(6):535-40.

5. Carvalho JC, Thylstrup A, Ekstrand KR. Results after 3 years of non-operative occlusal caries treatment of erupting permanent molars. Community Dent Oral Epidemiol 1992;20(4):187-92. 
Santos APP dos, Soviero VM. Caries prevalence and risk factors among children aged 0 to 36 months. Pesqui Odontol Bras 2002;16(3):203-208.

6. Cerqueira LM, Alves MSCF, Bönecker MJ, Pinho ALS. Estudo da prevalência de cárie e da dieta em crianças de 0 a 36 meses na cidade de Natal - RN 1999;2(9):351-6.

7. Davies GN. Early childhood caries - a synopsis. Community Dent Oral Epidemiol 1998;26 Suppl 1:106-16.

8. Eronat N, Eden E. A comparative study of some influencing factors of rampant or nursing caries in preschool children. J Clin Pediatr Dent 1992;16(4):275-9.

9. Fass EN. Is bottle-feeding of milk a factor in dental caries? ASDC J Dent Child 1962;29:245-51.

10. Gibson S, Williams S. Dental caries in preschool children: associations with social class, toothbrushing habit and consumption of sugars and sugar-containing foods. Caries Res 1999;33:101-13.

11. Grindefjord M, Dahllöf G, Ekström G, Höjer B, Modéer T. Caries prevalence in 2.5-year-old children. Caries Res 1993;27:505-10.

12. Hennon DK, Stookey GK, Muhler JC. Prevalence and distribution of dental caries in preschool children. J Am Dent Assoc 1969;79(6):1405-14.

13. Horowitz HS. Research issues in early childhood caries. Community Dent Oral Epidemiol 1998;26(1Suppl):6781.

14. Lopez del Valle L, Velazquez-Quintana Y, Weinstein P, Domoto P, Leroux B. Early childhood caries and risk factors in rural Puerto Rican children. ASDC J Dent Child 1998;65(2):132-5.

15. Medeiros UV, Souza MIC, Fonseca CT. Prevalência de cáries em pacientes bebês. J Bras Odontopediatr Odontol Bebê 1998;1(3):23-34.

16. Miceli VC, Soviero VM. Avaliação de um método para ensinar pais como diagnosticar a cárie precoce. Pesqui Odontol Bras 2000;14 Suppl:91.
17. Modesto A. Determinação do risco à doença cárie e da periodicidade das consultas de manutenção em crianças de 0 a 36 meses. J Bras Odontopediatr Odontol Bebê 1998;1(3):41-2.

18. Paunio P, Rautava P, Helenius H, Alanen P, Sillanpaa M. The Finnish family competence study: the relation between caries, dental health habits and general health in 3-year-old Finnish children. Caries Res 1993;27: 154-60.

19. Persson LA, Holm AK, Arvidsson S, Samuelson G. Infant feeding and dental caries - a longitudinal study of Swedish children. Swed Dent J 1985;9:201-6.

20. Ramos-Gomez FJ, Tomar SL, Ellison J, Artiga N, Sintes J, Vicuna G. Assessment of early childhood caries and dietary habits in a population of migrant Hispanic children in Stockton, California. ASDC J Dent Child 1999;66(6):395-403

21. Ribeiro AA. Avaliação de um programa de promoção de saúde bucal em crianças HIV+. [Dissertação de Mestrado] Rio de Janeiro : Faculdade de Odontologia da UFRJ; 2000.

22. Ribeiro A, Thylstrup A, Souza IP, Vianna R. Biofilme e atividade de cárie: sua correlação em crianças HIV+. [Abstract B102]. In: 16 ${ }^{\mathrm{a}}$ Reunião Anual da Sociedade Brasileira de Pesquisa Odontológica. São Paulo, set. 1999.

23. Tsubouchi J, Tsubouchi M, Maynard RJ, Domoto PK, Weinstein P. A study of dental caries and risk factors among native American infants. ASDC J Dent Child 1995;62(4):283-7.

24. Wyne AH, Adenubi JO, Shalan T, Khan N. Feeding and socioeconomic characteristics of nursing caries children in a Saudi population. Pediatr Dent 1995;17(7):451-4.

Recebido para publicação em 18/09/01

Enviado para reformulação em 27/04/02

Aceito para publicação em 19/06/02 